\title{
Milligram per Vial
}

National Cancer Institute

\section{Source}

National Cancer Institute. Milligram per Vial. NCI Thesaurus. Code C73745.

A vial dosing unit expressed in milligram(s) per vial. 